\title{
Michał Kozłowski
}

Dr inż.

Politechnika Warszawska, Wydział Transportu, Zakład Inżynierii Transportu Lotniczego

m.kozlowski@wt.pw.edu.pl

DOI: $10.35117 /$ A_ENG_18_12_08

\section{Standardization and integration of the airport master plan design process}

\begin{abstract}
The article presents the conclusion of the practical experience as well as the results of the author's research in the field of airport management, formulated in the context of the implementation of the investment of the Central Polish Airport. The subject of the considerations and implications is the process of designing the Airport Master Plan - AMP, which in the current situation should be modified in order to ensure effectiveness and efficiency of implementation and quality of results. At the beginning, AMP was characterized on the basis of a study concerning legal acts and selected standard documents, and a study of the quality and risk issues of the AMP was carried out. On the basis of the results obtained, conclusions have been formulated regarding the need for standardization and integration of the dynamic process of AMP design.
\end{abstract}

Keywords: Airport Master Plan; Project management; Standardization and Integration

\section{Characteristics of the General Plan of the Airport}

The statutory [42] obligation of the entities managing or establishing an airport of public use, which is the subject of consideration of the airport, is, inter alia, preparation of the General Plan of the Airport, and regarding the considerations of the General Plan of the Airport PGPL, the purpose of which is to document the development plan of the airport, and the subject, in particular:

- territorial scope,

- specification and values of surface parameters limiting aerial obstacles,

- concept of spatial development with the assumptions for the development of zones around the airport,

- air traffic development plan, including broken down into regular operations, charter and general aviation, transport of passengers and goods,

- the concept of providing air navigation services,

- capacity analysis, including its current (in the case of existing airports) and future parameters regarding: maneuvering field and aprons [43], terminals, air space and access roads to the airport and communication systems, in relation to the forecasted traffic development and planned airport modernization,

- economic and financial information regarding in particular the current and planned ownership structure, the expected sources of investment financing, current and expected profitability and liquidity of the entity, the planned amount of airport charges and income from them, with reference to the entity's total planned revenues,

as well as any other data, information and characteristics that significantly affect the current operation and future development of the airport.

The Act [42] specifies the requirement to prepare PGPL in a minimum 20-year time horizon and its updating in 5-year periods or more often if existing or designed technical and operational features of the aerodrome or economic, operational, environmental and financial conditions require significant changes. 
The PGPL project (and each update thereof) before approval (in terms of compliance with the country's transport policy) by the minister responsible for transport, is subject to:

- consultations with municipalities whose areas have been included in the territorial scope of PGL,

- opinion by the President of the Civil Aviation Office - ULC,

- agreement (in the aspect of compliance with government programs regarding the development of the country, including its individual regions) by the minister competent for regional development.

The approved PGPL is a formalized presentation (text and graphics) of a certain planning concept of the operation and development of a given airport [2, 43]. However, it should be borne in mind that PGL is not a strictly business plan document, but a set of prognostic operational and technical assumptions for the operation of an airport in a specific technical, operational, meteorological, environmental, market, economic and economic and legal environment. Due to this, the objective and subject matter of the legally prescribed [42] approval procedure for PGPL is only to ensure optimal and effective development of infrastructure and operation of the airport, in line with the general objectives and assumptions regarding transport and infrastructure development strategies [30] and regional development [29] in line with the principles of sustainable development, which is of particular importance for airports included in the TEN-T network [35]. As a rule, an approved PGPL is also not an investment program subject to direct implementation, nor does it restrict the freedom of economic activity of an airport managing entity, and as such cannot constitute an element of excessive State interference in the activities of airport managing entities [2, 31].

\section{The process of designing the General Plan of the Airport}

The general framework requirements and the standard of performance of PGPL have been defined by the International Civil Aviation Organization (ICAO) in ICAO Annex 14 [43] and the ICAO Doc 9184 Manual [2], which stipulate that PGPL is to present a planning concept of optimal development of the airport, based on logically combined and adequately aggregated results of research and analyzes regarding:

- forecasts of traffic volume and air transport,

- economic and financial issues,

- location criteria and methods,

- infrastructure,

- systems and operating processes,

- lane width,

- spatial development and environmental protection,

the methods of performance have been adequately specified in other ICAO publications, including Doc 8991 Manual on Air Traffic Forecasting, Doc 9157 Aerodrome Design Manual, Doc 9562 Airport Economics Manual, Doc 9889 Airport Air Quality Manual, creating a formal set of specifications and guidelines.

It is a common practice to use other methods and algorithms for the preparation of PGPL, as defined, for example, by the International Air Transport Association (IATA) [1] or developed on the basis of theory and scientific research $[12,19,25,26,27]$. This practice is a consequence of the high degree of generality of the referenced ICAO documents in the methodological sense, as well as the special significance of PGPL for the airport operator and the resulting needs regarding the substantive scope and level of detail of the PGPL content. 
In the sense of the theory of design methodology [8], the implementation of PGPL is the task of unitary engineering design, the result of which is preceded by implementation activities. The implementation of this design task includes the implementation of the following partial tasks:

- $\quad$ setting the goal, determining the scope, adopting assumptions,

- identification of requirements,

- design,

- construction,

- operation, and then modernization and extension, or liquidation or change of use, which are implemented in the formula of a systematic process. This process, due to the specificity of the objective and the subject as well as the broad and diverse substantive scope of PGPL, is a complex, iterative and interference engineering engineering process, including numerous activities, including:

- collection, verification and aggregation of input and inter-stage data and information,

- defining project variants, selection criteria and making decisions,

- defining goals and optimization criteria and making decisions,

and direct actions that lead to the achievement of the final result, i.e. analysis and design, using specific methods and algorithms whose selection is to a large extent an arbitrary decision of the PGPL Contractor.

The implementation of the PGPL design process is characterized by creative and synergic interdisciplinary conceptualization of the way the objectives are implemented in a very wide range of issues, in particular: infrastructure and aircraft, ground-based equipment, social and economic conditions, forecasts of traffic volume and structure and air transport, environmental aspects, air carrier strategies, strategic objectives, assumptions and directions of transport development defined in the Community, national and regional dimension [22].

The resources [11] of the PGPL design process are:

- sponsor and clients as well as stakeholders and beneficiaries of the project,

- the project team,

- project management methodology,

- data and information collections,

and methods for collecting, aggregating and processing data sets that differ in scope and degree of specificity, and the level of integrity and cohesion.

The appropriateness and adequacy of PGPL project resources and relationships depend on the quality of the results of the PGL project, which in particular applies to project team members who should belong to experts in specific fields, undertaking arbitrary decisions regarding the selection and use of data sets and the choice of methods and tools. Previous research [22] shows that the critical resource of the PGPL project is the members of the project team who must meet the requirements regarding, in particular:

- level of substantive competences,

- motivation and ability to accept responsibility,

- teamwork skills and activity and effectiveness.

Another important factor, significantly determining the course of implementation and the quality of the results of the PGPL project, is the management of data and information resources and communication, in particular in the field of consultations, which is a component of knowledge management and project repository, and what in the aspect of explicit and implicit knowledge of the project has a significant impact on the quality and risk of the PGL project implementation, the quality of results and the risk of their application [6]. 


\section{Quality and risk of the design process of the General Plan of the Airport}

Regardless of the chosen algorithms and methods of implementation of individual partial tasks as well as management of the PGPL project implementation, the characteristic feature of the PGPL design process is the presence of factors [9, 22]:

- volatility of airlines' policies and strategies,

- development and improvement of aircraft construction,

- uncertainty of forecasts and prognostic analyzes, the degree of which increases with the increase of the time horizon,

- potential competition between airports and the resulting contradiction of goals and assumptions,

- potential competition between the airport and other modes of transport and the resulting conflicts of objectives and assumptions,

- potentially conflicting or divergent goals and selection criteria determined internally by the PGPL Contractor and determined externally (e.g. transport policy, development plan and spatial development plan),

which factors will be randomly and dynamically variable in the 20-year time horizon of the PGPL development, as well as to a lesser extent in the five-year PGPL update periods.

An important issue is also the hierarchical subordination of the PGPL design process to political, economic and spatial planning at the State level [9].

In such circumstances, the quality of PGPL understood as the degree of meeting the requirements [39] and expectations is becoming a significant problem issue:

- clients of the PGPL design process, which primarily include airport managing bodies and government administration bodies, competent in matters of aviation, transport and infrastructure, development and the economy,

- stakeholders, including air carriers, ground handling agents, air traffic service providers, the local community remaining in the airport's airport gravity area, managing other airport operators and carriers and infrastructure managers of other modes of transport,

determined in particular by the availability and consistency of input data, adequacy of selected methods and their correct application, competences of members of the PGPL Project team, effectiveness of consultation processes with direct users and stakeholders of PGPL.

It should be noted that the PGPL quality issue must be considered in a broader context than just limited to the airport being a PGPL entity. Complex relationships and formal, legal, organizational, operational and economic conditions determine the need to consider the quality of PGPL, taking into account that the airport being its subject is:

- a special kind of public utility airport [43],

- a highly complex technical system [14, 23],

- a highly complex functional system $[18,19]$,

- one of many on the competitive air transport market [3, 4, 5, 28, 30],

- element of the air transport system [30, 38],

- a multimodal element of the integrated transport system [13, 21, 35, 38], which can be considered as a link in the integrated supply chain [24],

- a factor of regional development [29] and socio-economic [17],

whose exploitation takes place in a dynamically and independently changing environment and conditions [16, 19, 24, 37] and is subject to numerous disruptive factors: technical, environmental, operational and remains in connection with:

- technical reliability of infrastructure elements [14, 23],

- airspace and air traffic management [7, 25, 34],

- the population of operating aircraft and traffic flow structures [20, 25]. 
This sets the risk context for the management and operation of the airport [15, 16, 17, 24], the causes of which are disturbances, damage to infrastructure and other emergency situations, resulting in congestion and reduced airport capacity [26, 27, 37] and readiness operational [20] or discontinuation of airport operations [14, 19].

This risk, in particular in the aspect of the possibility of its reduction [44] (e.g. by adding surpluses to the airport's reliability structure [19] in the assumptions of investment projects), is not included in the PGPL subject, which is a significant and unwarranted weakness of formal PGPL specifications.

It is also significant that the PGPL's formal specifications omit risk issues, both the risk of project implementation and the risk resulting from the assumption and implementation of the assumptions and concepts of the approved PGPL [22], resulting from the occurrence of numerous factors of variability and indeterminacy [9]. This is in obvious contradiction with the requirements and legal and actual interests of the clients and stakeholders of the PGPL design process. The result is the search and use of various methods in the PGPL design process, giving the opportunity to obtain results with a range and quality that meet specific requirements and comply with the adopted assumptions. Thus, a set of heterogeneously substantive and qualitative general plans of individual airports is created, which can be defined by the concept of "incompatibility", which significantly hinders and limits the possibility of their integrated and systematic use on each problem level of systems and transport processes management, i.e. adaptation, optimization and regulation, both at the micro-single airport $[18,21]$ and macro scale - transport systems and networks $[13,35,38]$.

\section{The issue of standardization and integration of the design process of the General Plan of the Airport}

The PGPL design process is a highly complex process that can be implemented with a static (based on relatively simple deterministic algorithms [1,2]) or dynamic (taking into account the random variability of independent factors $[9,11]$ ) methodical approach, each of which omits aspects standardization and integration of design methods and principles and procedures of PGPL project management, which is however a practical need. In this state of affairs, actions were taken aimed at developing more detailed than formal specifications [2, 43], guidelines for a uniform method of preparing and coherent presentation of PGPL results, on a national scale (e.g. [10]), based on scientific publications (e.g. [9, 12]).

Such actions (unsuccessfully) were also taken in Poland. In 2013, the Ministry of Transport launched an initiative (in cooperation with ULC, Ministry of Regional Development, Ministry of National Defense, PANSA, Airports and Association of Regional Airports) document defining the substantive scope and formal content of PGPL, constituting a specific consensus and fulfilling the desiderata of the involved entities [31]. This initiative was a response to the needs of airport operators to harmonize and specify the requirements, methods, and standards of PGPL design in a manner consistent with the law and national [30] and Community $[13,35]$ strategic documents and programs in the field of air transport. , respecting the principles of sustainable development [24] and the concept of spatial development. The draft guidelines were prepared on the basis of numerous international publications $[1,2,12,43]$ and national $[25,26,97]$ and included in its scope detailed technical specifications and methodological guidelines.

In the current formal and actual state $[36,40]$ resulting from the decisions taken on the implementation of the investment of the Central Communication Port - CPK, updating PGPL has become a particularly difficult task. The uncertainty of the CPK's potential impact on the market and the structure of air transport and the distribution of air traffic in the airspace and between individual airports, as well as government decisions, means that it is necessary to adopt a certain standard for updating already approved PGPLs, based on the synergic 
integration of government parties, port managers Air carriers and other stakeholders, in particular air carriers, without which successive editions of the PGPL will be only worthless documents fulfilling the statutory obligation [42]. It should be borne in mind that the CPK investment is based, next to the statutory provisions issued so far [41, 42], on the rules and procedures for the management and implementation of CPK investments and accompanying investments and other projects related to the construction of the CPK [40], with the leading role of the Government Plenipotentiary for the Central Communication Port for the Republic of Poland, being the secretary of state in the Chancellery of the Prime Minister, whose tasks include in particular preparing and supervising the implementation of the CPK investment, including in particular [36]:

- analysis of legal, technical and economic conditions for the preparation and implementation of investments;

- preparation of project assumptions for investments and concepts of implementation of activities necessary to carry out investments;

- preparing proposals for legislative changes and changes in government strategic documents necessary to carry out the investment.

The scope of statutory regulations [40] cited above and competences of the CPK Representative show that both CPK investment processes as well as legislative and program changes in the field of air transport will be dynamic, which should be properly considered when updating the approved PGPL.

In particular, the subject of the standard of preparation (and updates already approved) PGPL should adequately and uniformly determine:

1. the distinction between detailed specifications for existing and newly established airports, respectively

2. rules for determining project criteria and making decisions with their application [11], e.g. location $[2,43]$,

3. a method for determining the value of the airport's utilization rate [43],

4. the method of calculating the airport's operational readiness [20],

5. a method of assessing the balancing of airport usability and operational readiness values $[18,20,43]$,

6. the method of analyzing the capacity of the maneuvering area, aprons and terminals of the airport, as well as the scope and level of detail of the presented results $[9,12,27]$,

7. method of prognostic assessment of the degree of capacity saturation and rules for interpreting results [26],

8. method for assessing the balancing of capacity and capacity of particular airport subsystems, i.e.: CTR and TMA, maneuvering area, aprons, including de-icing, passenger and freight terminals, rail and road transport systems, car parks, etc. [1, $18,21,27]$,

9. methods of analysis and management of airport operation risk [15, 16, 17, 32, 44], including business continuity [14, 19],

10. a method of analyzing the capacity to meet the demand for air transport $[1,9]$,

11. how to specify CTR specifications and TMA requirements and provide ATS services [7],

12. the structure of relations and the manner of publishing other documents required by regulations [42], e.g. airport utilization program, forecast and plan of air traffic organization at the airport and its area, indicating ways to avoid collision with traffic from existing neighboring airports, extract and outline from the local zoning plan for the area of the airport and its surrounding areas in the zone of its impact, a copy of the decision on the location of the public purpose investment, a copy of 
the decision on building conditions, a copy of the decision on the permit for the public airport investment or a copy of the decision determining the location of investment in the CPK [40], in order to reduce the number of documents being prepared and to eliminate duplication of content,

13. "milestones", which are decision-making points for the implementation of individual tasks specified in PGPL, related to the results of relevant analyzes and updated forecasts.

Adoption and uniform application of the standards set out above will ensure consistency of new or updated PGPLs, and the quality of implementation processes, results and effects of use can be effectively ensured by introducing procedures ensuring integrated implementation of PGPL's design processes, in particular through:

- introducing the obligation to prepare forecasts of demand for traffic and air transport to a competent authority, e.g. ULC or CSO, adopting uniform assumptions and consistent input data and submitting the results of these forecasts to PGPL's contractors for uniform and consistent use,

- implementation of information exchange and consultation procedures between the Contractor of PGL and other relevant entities operating in the field of civil aviation, in particular air carriers and PANSA as well as other institutions and entities, e.g. GDDKiA, PKP,

- implementation of the procedure for identifying currently applicable legal requirements and other requirements applicable to PGPL design.

\section{Summary}

The substantive scope and the level of detail of currently binding formal specifications $[2,42$, 43] of PGPL preparation do not provide acceptable levels of risk and quality of the PGPL design process [22], consistent with practical requirements [22] and the use of its results [9]. This is a particularly important problem in the context of the CPK investment. As results from the research [22] of critical resources and assets of the PGPL project, next to the project team members are methods and data resources that should be used in a systematic, uniform and repeatable manner. This results from the desirability of developing and applying uniformly the analysis methods and implementing PGPL project management principles and procedures, including components for quality assurance and risk management $[11,22,32,39,44]$. In the context of these procedures, particular importance should be attached to consultation and information exchange procedures [11, 39, 44].

The development, and then their uniform, effective and effective application of the above methods, principles, and procedures, ensuring standardization and integration of PGPL design processes, also requires undertaking appropriate organizational measures, with appropriate participation of representatives of relevant institutions and entities. It will be reasonable to apply solutions analogous to those already existing and properly functioning, i.e. substantive extension and refinement of the competencies of the air carriers committees at airports and airport user committees [33, 42], the Airspace Management Committee [34], and in particular the Council to matters related to the construction of the Central Communication Port, which is an advisory body to the CPK Plenipotentiary regarding the implementation and functioning of the CPK investment. Another option seems to be the appointment of a separate consultative body to the President of the ULC or the minister responsible for transport.

However, taking into account the information published in the press about decisions taken at governmental level to close the airport. F. Chopin in Warsaw, when the CPK is launched, the property of the Association of Regional Airports should be considered, the purpose of which is to organize and systematize the cooperation of regional airports, including in the area 
of investment processes and modernization as well as the development of common airport quality standards.

\section{Source materials}

[1] Airport Development Reference Manual. IATA ADRM

[2] Airport Planning Manual, Part 1 Master Planning. ICAO Doc 9184

[3] Augustyniak W., Kalinowski S. Benchmarking oraz metody mierzenia efektywności portów lotniczych. W: Rekowski M. (red.), Regionalne porty lotnicze w Polsce charakterystyka i tendencje rozwojowe. Wydawnictwo Uniwersytetu Ekonomicznego w Poznaniu, 2011, s. 239-255.

[4] Augustyniak W. Kryteria oceny portów lotniczych przez linie lotnicze, Przegląd Komunikacyjny, Nr 7, 2013, ss. 8-12

[5] Augustyniak W. Efektywność finansowa i techniczna regionalnych portów lotniczych w Polsce. Przegląd Komunikacyjny, Nr 2, 2012, ss. 8-15

[6] Balek J., Valuch M., Ižvolt L., Pawlicki J., Čuraj M.: Poprawa jakości projektów budowli transportowych $\mathrm{z}$ wykorzystaniem metod zarządzania wiedzą. Zeszyty Naukowe Politechniki Śląskiej, seria Transport z. 65/2009, ss. 5-11

[7] Banaszek K., Kozłowski M. Operacyjne aspekty koncepcji utworzenia duoportu dla aglomeracji warszawskiej. W: Skorupski J. (red.) Wyzwania inżynierii ruchu lotniczego. Wydział Transportu Politechniki Warszawskiej, 2016, ss. 29-38

[8] Basiewicz T. Metodologia projektowania w inżynierii transportu. Wydawnictwo Politechniki Warszawskiej, 1987

[9] Belobaba P., Neufville R., Odoni A. R., Reynolds G. Airport Systems Planning, Design and Management. McGraw-Hill, 2013.

[10] Federal Aviation Administration. Airport Master Plans. U.S. Department of Transportation Advisory Circular AC 150/5070-6B, 2007

[11] Guidance on project management. ISO 21500:2012

[12] Horonjeff R., McKelvey F. X., Sproule W. J., Young S. B. Planning and Design of Airports. The McGraw-Hill, NY, 2010

[13] Komunikat Komisji - Sieci transeuropejskie: W kierunku podejścia zintegrowanego. $\operatorname{COM}(2007) 135$

[14] Kozłowski M. Aspect of reliability in airport business continuity management. Journal of KONBiN, No 3, 2015, ss. 43-50

[15] Kozłowski M. Aspekt standaryzacji w procesie zintegrowanego zarządzania ryzykiem. Przegląd Komunikacyjny, nr 11, 2014, ss. 40-43

[16] Kozłowski M. Kontekst zintegrowanego zarządzania ryzykiem operacyjnym w porcie lotniczym. W: Radomyski A. i in. (red) Współczesne aspekty bezpieczeństwa w transporcie lotniczym. Wyższa Szkoła Oficerska Sił Powietrznych w Dęblinie, 2017, ss. $197-207$

[17] Kozłowski M. Społeczno-gospodarczy kontekst zarządzania ryzykiem eksploatacji portu lotniczego. Logistyka - czasopismo dla profesjonalistów, nr 3, 2015, ss. 23962405

[18] Kozłowski M. Systemowe ujęcie zagadnienia analizy i kształtowania charakterystyk funkcjonalnych lotniska komunikacyjnego. Konferencja „Lotnictwo w Polsce na początku XXI wieku”, Radom, $2001 \mathrm{r}$.

[19] Kozłowski M. The concept of method for determining the minimum level of airport business continuity. Journal of KONBiN, vol. 1, No 37, 2016, ss. 5-22

[20] Kozłowski M., Malarski M. Gotowość operacyjna portu lotniczego dla różnej struktury potoku obsługiwanych statków powietrznych. Konferencja „Transport XXI wieku", Tom II, Warszawa, 2004 
[21] Kozłowski M., Marczewski R., Winiewski A. Zagadnienie przepustowości portu lotniczego rozpatrywanego w aspekcie węzła multimodalnej sieci transportowej. II Konferencja TIL, Kielce, 2008 r.

[22] Kozłowski M., Stelmach A. Zarządzanie jakością i ryzykiem projektu planu generalnego portu lotniczego. Prace Naukowe Politechniki Warszawskiej. Transport, nr 118, 2017, ss. 131-143

[23] Kozłowski M., Skorupski J., Stelmach A. Simulation analysis of aerodrome CNS system reliability. W: Stein H. i in. (red.) Safety and Reliability - Safe Societies in a Changing World, Taylor \& Francis Group, 2018, ss. 2505-2511

[24] Kozłowski M., Syta J. Koncepcja zarządzania ryzykiem w łańcuchu dostaw portu lotniczego. W: Radomyski A. i in. (red) Współczesne aspekty bezpieczeństwa w transporcie lotniczym. Wyższa Szkoła Oficerska Sił Powietrznych w Dęblinie, 2017, Ss. 179-195

[25] Malarski M., Skorupski J. Modelowanie przestrzeni lotniska w celu wyznaczenia jego pojemności dla różnych systemów organizacji ruchu lotniczego. Zeszyty Naukowe Politechniki Śląskiej, seria Automatyka, nr 115, 1994, ss. 93-102

[26] Malarski M., Skorupski J. Metoda modelowania pracy portu lotniczego wykorzystująca kongestię ruchu. W: Sympozjum naukowe Przepustowość polskich lotnisk komunikacyjnych w aspekcie realizacji programu HUB dla lotniska Warszawa Okęcie im. Fryderyka Chopina / Praca Zbiorowa, 2002, ss. 81-86

[27] Malarski M., Skorupski J. Metoda wyznaczania pojemności lotniska. W: Sympozjum naukowe Przepustowość polskich lotnisk komunikacyjnych w aspekcie realizacji programu HUB dla lotniska Warszawa Okęcie im. Fryderyka Chopina / Praca Zbiorowa, 2002, ss. 75-80

[28] Marciszewska E. Jakość w procesie kształtowania przewag konkurencyjnych na rynku. W: Transport morski i lotniczy w obsłudze ruchu pasażerskiego. Implikacje dla regionów. Zeszyt Naukowy nr 491 Uniwersytet Szczeciński, Szczecin 2008

[29] Marciszewska E.. Kaliński D. Port lotniczy jako czynnik rozwoju regionalnego. W: Barski A., Fabirkiewicz W., Jarosza Cz. Rozwój lotnictwa w regionach. Toruń, 2009

[30] Program Rozwoju Sieci Lotnisk i Lotniczych Urządzeń Naziemnych; przyjęty Uchwałą Rady Ministrów dnia 8 maja 2007 r.

[31] Projekt wytycznych do planu generalnego lotnisk użytku publicznego. Ministerstwo Transportu Budownictwa i Gospodarki Morskiej, 2013

[32] Risk management - Risk assessment techniques. ISO/IEC 31010:2009.

[33] Rozporządzenie Ministra Infrastruktury z dnia 30 kwietnia 2004 r. w sprawie tworzenia i działania komitetów oraz współdziałania i konsultacji w porcie lotniczym. Dz.U. z 2004 r. Nr 103, poz. 1088

[34] Rozporządzenie Ministra Infrastruktury z dnia 12 września 2008 r. w sprawie Komitetu Zarządzania Przestrzenią Powietrzną oraz ustalenia zakresu jego działania. Dz. U. z 2014 r., poz. 1173

[35] Rozporządzenie Parlamentu Europejskiego i Rady (UE) NR 1315/2013 z dnia 11 grudnia 2013 r. w sprawie unijnych wytycznych dotyczących rozwoju transeuropejskiej sieci transportowej i uchylające decyzję nr 661/2010/UE. Dziennik Urzędowy Unii Europejskiej L 348/1 PL

[36] Rozporządzenie Rady Ministrów z dnia 27 kwietnia 2017 r. w sprawie ustanowienia Pełnomocnika Rządu do spraw Centralnego Portu Komunikacyjnego dla Rzeczypospolitej Polskiej. Dz.U. z 2017 r., poz. 874

[37] Skorupski J., Kozłowski M., Stelmach A. Metoda badania przepustowości portu lotniczego w warunkach zakłóceń. W: Problemy Niezawodności Systemów. Polska Akademia Nauk, 2007, ss. 288-298 
[38] Sprawozdanie Komisji dla Parlamentu Europejskiego, Rady, Europejskiego Komitetu Ekonomiczno-Społecznego i Komitetu Regionów - Sprawozdanie z postępu prac we wdrażaniu sieci TEN-T w latach 2014-2015. COM(2017) 327

[39] Systemy zarządzania jakością - Wymagania. PN-EN ISO 9001:2015-10

[40] Ustawa z dnia 10 maja 2018 r. o Centralnym Porcie Komunikacyjnym. Dz.U. z 2018 r., poz. 1089

[41] Ustawa z dnia 12 lutego 2009 r. o szczególnych zasadach przygotowania i realizacji inwestycji w zakresie lotnisk użytku publicznego. Dz.U. z 2009 r. Nr 42, poz. 340

[42] Ustawa z dnia 3 lipca 2002 r. Prawo lotnicze. Dz.U. z 2018 r., poz. 1183

[43] Załącznik 14 do Konwencji o Międzynarodowym Lotnictwie Cywilnym. Lotniska, Tom I - Projektowanie i eksploatacja lotnisk

[44] Zarządzanie ryzykiem - Zasady i wytyczne. PN-ISO 31000:2012 